\title{
PENYIDIKAN TINDAK PIDANA PERBANKAN DALAM BENTUK PENGGELAPAN DANA NASABAH KREDIT USAHA RAKYAT PADA PT. BRI CABANG KATIB SULAIMAN \\ (Studi Kasus LP/198/VII/2019/SPKT Sbr)
}

\author{
Filsuf Yudhistira ${ }^{1}$, Iayah Faniyah ${ }^{2}$ \\ ${ }^{1)}$ Program Magister Ilmu Hukum,Universitas Ekasakti, Padang, Indonesia \\ Email: yudhistirafilsuf@gmail.com \\ ${ }^{2)}$ Universitas Ekasakti, Padang, Indonesia \\ Email: iyahfaniyah@unespadang.ac.id
}

\begin{abstract}
Banks have a strategic role to support the implementation of national development and increase equitable development. The precautionary principle is the principle in collecting and distributing public funds. This is regulated in Law Number 10 of 1998 concerning Amendments to Law Number 7 of 1992 concerning Banking. The priority of operating a bank is to protect the interests of customers who entrust their funds to the bank. However, there was a banking crime that occurred at PT. BRI Branch Katib Sulaiman, as stated in the police report number LP/198/VII/2019/SPKT Sbr. In this case, in addition to injuring public trust, it also caused losses to the bank where there were unscrupulous bank employees who had embezzled customer funds.
\end{abstract}

Keywords: Investigation, Customers, People's Business Credit

\section{ABSTRAK}

Bank memiliki peranan yang strategis untuk menunjang pelaksanaan pembangunan nasional dan meningkatkan pemerataan pembangunan. Prinsip kehati-hatian merupakan asas dalam penghimpun dan penyalur dana masyarakat. Hal ini diatur dalam Undang-Undang Nomor 10 Tahun 1998 tentang Perubahan Atas Undang-Undang Nomor 7 Tahun 1992 tentang Perbankan. Keutamaan penyelenggaraan bank adalah untuk menjaga kepentingan nasabah yang mempercayakan dananya kepada bank. Namun, terdapat tindak pidana perbankan yang terjadi pada PT Cabang BRI Katib Sulaiman, sebagaimana pada laporan polisi nomor LP/198/VII/2019/SPKT Sbr. Dalam perkara tersebut, disamping menciderai kepercayaan masyarakat, juga menimbulkan kerugian bagi bank yang mana terdapat oknum karyawan bank yang telah menggelapkan dana nasabah.

Kata Kunci: Penyidikan, Nasabah, Kredit Usaha Rakyat

\section{PENDAHULUAN}

Perkembangan ekonomi nasional dewasa ini menunjukkan arah yang semakin menyatu dengan ekonomi regional dan internasional yang dapat menunjang sekaligus dapat berdampak kurang menguntungkan. Sementara itu, perkembangan perekonomian nasional senantiasa bergerak cepat dengan tantangan yang semakin kompleks. Salah satu tantangan 
ialah pada modal yang dibutuhkan oleh para pengusaha kecil dan menengah atau biasa dikenal dengan Usaha Mikro Kecil Menengah (UMKM).

Pemberdayaan usaha mikro, kecil, dan menengah perlu diselenggarakan secara menyeluruh, optimal serta berkesinambungan melalui pengembangan iklim yang kondusif, pemberian kesempatan berusaha, dukungan, perlindungan dan pengembangan usaha seluasluasnya, sehingga mampu meningkatkan kedudukan, peran dan potensi usaha mikro, kecil dan menengah dalam mewujudkan pertumbuhan ekonomi, pemerataan dan peningkatan pendapatan rakyat, penciptaan lapangan kerja, dan pengentasan kemiskinan. Melalui Instruksi Presiden Nomor 6 Tahun 2007 tentang Kebijakan Percepatan, Pengembangan Sektor Riil, dan Pemberdayaan Usaha Mikro, Kecil dan Menengah, dimana merupakan salah satu yang menjadi dasar hukum dibidang pengembangan usaha mikro, kecil, dan menengah. ${ }^{1}$

Berkaitan dengan hal tersebut diatas, adapun yang dimaksud dengan usaha mikro, kecil, dan menengah menurut Pasal 1 angka 1, 2, 3 pada Undang-Undang Nomor 20 Tahun 2008 tentang Usaha Mikro Kecil dan Menengah yang menyebutkan sebagai berikut:

Pasal 1 angka 1, menyebutkan bahwa: Usaha Mikro adalah usaha produktif milik orang perorangan dan/atau badan usaha perorangan yang memenuhi kriteria Usaha Mikro sebagaimana diatur dalam Undang-Undang ini.

Pasal 1 angka 2, menyebutkan bahwa: Usaha Kecil adalah usaha ekonomi produktif yang berdiri sendiri, yang dilakukan oleh orang perorangan atau badan usaha yang bukan merupakan anak perusahaan atau bukan cabang perusahaan yang dimiliki, dikuasai, atau menjadi bagian baik langsung maupun tidak langsung dari Usaha Menengah atau Usaha Besar yang memenuhi kriteria Usaha Kecil sebagaimana dimaksud dalam Undang-Undang ini.

Pasal 1 angka 3, menyebutkan bahwa: Usaha Menengah adalah usaha ekonomi produktif yang berdiri sendiri, yang dilakukan oleh orang perorangan atau badan usaha yang bukan merupakan anak perusahaan atau cabang perusahaan yang dimiliki, dikuasai, atau menjadi bagian baik langsung maupun tidak langsung dengan Usaha Kecil atau Usaha Besar dengan jumlah kekayaan bersih atau hasil penjualan tahunan sebagaimana diatur dalam UndangUndang ini.

Langkah-langkah dalam pengembangan usaha mikro, kecil, dan menengah, yang diatur dalam Instruksi Presiden Nomor 6 Tahun 2007 tentang Kebijakan Percepatan, Pengembangan Sektor Riil dan Pemberdayaan Usaha Mikro, Kecil dan Menengah, diantaranya adalah pemberdayaan usaha mikro, kecil dan menengah yang dituangkan dalam lampiran Instruksi Presiden Republik Indonesia nomor 6 Tahun 2007 pada tanggal 8 Juni 2007, menyebutkan bahwa: ${ }^{2}$

1. Meningkatkan kapasitas kelembagaan dan akses UMKM pada sumber pembiayaan.

2. Memperkuat sistem penjamin kredit bagi UMKM.

3. Pengembangan sistem resi gudang sebagai instrument pembiayaan bagi UMKM.

4. Memaksimalkan pemanfaatan dana non-perbankan untuk pemberdayaan UMKM.

\footnotetext{
${ }^{1}$ https://www.simulasikredit.com/apa-itu-kredit-usaha-rakyat-kur-kur-mikro-kur-retailkur-tki

${ }^{2}$ Feni Dwi Anggraeni, Pengembangan Usaha Mikro, Kecil, Dan Menengah (Umkm) Melalui Fasilitasi Pihak

Eksternal Dan Potensi Internal, Jurnal Administrasi Publik (JAP), Vol. 1, No. 6, 2009, hlm. 128.
} 
5. Meningkatkan efektivitas pemanfaatan dana bergulir APBN untuk pemberdayaan UMKM dengan menertibkan panduan tentang Pengelolaa Dana APBN untuk pemberdaan UMKM, termasuk panduan yang dikeluarkan dalam Peraturan Menteri Keuangan.

6. Restrukturisasi pengelolaan dana Program Kemitraan dan Bina Lingkungan (PKBL) pada BUMN.

Dalam mewujudkan langkah-langkah tersebut, maka pada tanggal 05 November 2007, Presiden Republik Indonesia Susilo Bambang Yudhoyono meresmikan kredit bagi UMKM dengan pola penjaminan tersebut dengan nama Kredit Usaha Rakyat (KUR). Kebijakan penjaminan kredit ini diharapkan akan dapat memberikan kemudahan akses yang lebih besar bagi para pelaku UMKM dan Koperasi yang telah feasible namun belum bankable. Setelah dikeluarkannya Instruksi Presiden Nomor 6 Tahun 2007 tentang Kebijakan Percepatan, Pengembangan Sektor Riil dan Pemberdayaan Usaha Mikro, Kecil dan Menengah.

\section{PEMBAHASAN}

A. Penyidikan Tindak Pidana Perbankan Dalam Bentuk Penggelapan Dana Nasabah Kredit Usaha Rakyat Pada PT. BRI Cabang Katib Sulaiman Berdasarkan Laporan Polisi Nomor LP/198/VII/2019/SPKT Sbr

Berdasarkan hasil penelitan pada perkara tindak pidana perbankan dalam bentuk penggelapan dana nasabah kredit usaha rakyat sebagaimana dalam laporan polisi nomor: LP/198/VII/2019/SPKT SBR yang ditangani Subdit II Perbankan Direktorat Reserse Kriminal Khusus (Ditreskrimsus) Kepolisian Daerah Sumatera Barat. Menurut Kompol Yanisman, S.H, penyidikan dalam perkara ini hanya dapat dilakukan setelah adanya pengaduan dari pihak yang dirugikan atau yang telah menjadi korban, karena dalam tindak pidana perbankan dalam bentuk penggelapan dana nasabah kredit usaha rakyat ini merupakan tindak pidana dengan delik aduan dan yang berwenang dalam penanganan perkara ini yakni Subdit II Perbankan Ditreskrimsus Polda Sumatera Barat, karena perkara ini merupakan tindak pidana khusus.

Sebagaimana yang diketahui pada bab sebelumnya, dimana perakara ini bermula dari adanya laporan dari pelapor atas nama Medani Hidayat Pgl Med (saksi pelapor) di Polda Sumatera Barat yang diterima oleh Brigadir Irwan Syamzani, S.S sebagai Penyidik Pembantu dan dibawah perintah Kompol Yanisman, S.H selaku Kasubdit II Perbankan pada Ditreskrimsus Polda Sumatera Barat atas dugaan telah terjadinya tindak pidana perbankan dalam bentuk penggelapan dana nasabah kredit usaha rakyat Kantor Unit Belimbing PT BRI Cab. Khatib Sulaiman yang kemudian dituangkan dalam Laporan Polisi Nomor: LP/198/VII/2019/SPKT SBR tertanggal 29 Juli 2019.

Berdasarkan laporan tersebut, kemudian Penyidik Ditreskrimsus Polda Sumatera Barat melaksanakan penyidikan yang didahului dengan penyelidikan dengan mengunjungi tempat kejadian perkara guna menemukan dan mengumpulkan bukti permulaan yang cukup dengan melakukan upaya hukum penyitaan terhadap barang bukti yang berhubungan dengan perkara berdasarkan Surat Perintah Penyitaan Nomor: Surat Perintah Penyitaan Nomor: Sp.Sita/33/ XI/RES.2.2/2019/ Ditreskrimsus, tanggal 20 November 2019 , telah dilakukan penyitaan terhadap barang bukti sebagaimana yang telah disebutkan dalam bab sebelumnya.

Berdasarkan penyitaan barang bukti dari hasil penyelidikan tersebut kemudian 
Penyidik Ditreskrimsus Polda Sumatera Barat menerbitkan Surat Perintah Penyidikan Nomor: Sp.Sidik/43/IX/RES.2.2/2019/Ditreskrimsus tanggal 19 September 2019 yang kemudian diterbitkannya Surat Pemberitahuan Dimulainya Penyidikan Nomor:SPDP/26/XI/RES.2.2./2019/Ditreskrimsus tanggal 19 September 2019 ke Kejaksaan Negeri Padang Pariaman. Dalam melaksanakan penyidikan, penyidik telah melakukan pemanggilan serta mengadakan pemeriksaan terhadap saksi-saksi sebagai yang telah diuraikan dalam bab hasil penelitian.

Dalam perkara ini, Penyidik juga melakukan pemanggilan terhadap ahli berdasarkan Surat Ditreskrimsus Polda Sumbar Nomor: R/1257/IX/RES.2.2/ 2019/Ditreskrimsus tanggal 20 September 2019, tentang Permintaan Ahli Perbankan, untuk memberikan keterangan terkait dengan perkara tindak pidana perbankan dalam bentuk penggelapan dana nasabah kredit usaha rakyat. Berdasarkan Surat Dewan Komisioner Otoritas Jasa Keuangan Nomor: S84/MS. 61/2019 tanggal 1 Oktober 2019 perihal Penunjukan Ahli, dari Investigator Eksekutif Senior pada Direktorat Investigasi Perbankan atas nama Sdr. Syahrial Aziz dan telah dilakukan pemeriksaan pada hari Kamis tanggal 3 Oktober 2019.

Selanjutnya, penyidik melakukan upaya paksa penangkapan terhadap tersangka, pada hari Selasa tanggal 31 Desember 2019 sekira pukul 18.30 WIB di Perum Griya Ketaping Blok A No. 1 Jorong Talao Mundam Nagari Ketaping Kecamatan Batang Anai Kabupaten Padang Pariaman. Berdasarkan Surat Perintah Penangkapan Nomor: Sp. Kap/06/XII/2019/Ditreskrimsus tanggal 23 Desember 2019.

Kemudian dari hasil penangkapan tersebut, terhadap tersangka dilakukan upaya paksa penahanan berdasarkan pada Surat Perintah Penahan Nomor: Sp. Han/1/I/RES.2.2/2020/Ditreskrimsus, tanggal 1 Januari 2020 telah dilakukan upaya paksa penahanan di Rumah Tahanan Polda Sumbar terhitung mulai tanggal 1 Januari 2020 sampai dengan 20 Januari 2020 dan telah dibuatkan Berita Acara Penahanan. Berdasarkan hasil penahanan tersebut, maka dilakukan pemeriksaan terhadap tersangka yang didampingi oleh Pengacara atau Penasehat Hukum dari RJ Law Firm atas nama Rahmi Jasim, S.H., M.H dimana tersangka pada pokoknya menerangkan bahwa:

1. Tersangka menjelaskan bahwa tersangka melakukan penyetoran dana hasil transaksi penagihan Kredit KUR yaitu dengan menyerahkan bukti slip setoran yang berwarna Putih kepada Teller Bank BRI kantor Unit Belimbing Cab. Khatib Sulaiman yang telah diisi dan ditanda tangani nasabah sesuai dengan jumlah angsuran yang telah disetorkan ke pada tersangka, kemudian keesokan harinya tersangka melakukan pengecekan di sistem BRInet untuk mengetahui apakah dana angsuran yang tersangka terima dari nasabah tersebut telah masuk ke rekening kredit pinjaman nasabah.

2. Tersangka menjelaskan bahwa setelah pemeriksa memperlihatkan Foto Copy Legalisir Slip setoran kepada tersangka, tersangka mengetahui foto copy legalisir dokumendokumen tersebut yang mana merupakan bukti tanda terima penyetoran angsuran kredit KUR nasabah Kantor unit Belimbing PT. BRI Cab Khatib Sulaiman yang penyetoranya melalui tersangka.

3. Kemudian tersangka menjelaskan bahwa terhadap dana hasil transaksi penagihan tersebut di atas tidak tersangka setorkan ke Teller Bank kantor Unit Belimbing Cab. Khatib Sulaiman, yang mana seharusnya dana hasil transaksi penagihan tersebut harus 
tersangka setorkan ke teller bank pada hari yang sama saat tersangka melakukan penagihan.

4. Terasangka menjelaskan terhadap sejumlah dana dari hasil penagihan yang tersangka lakukan kepada 32 Nasabah kredit KUR Kantor Unit Belimbing Cab. Khatib Sulaiman, yang tidak tersangka setorkan ke Teller Bank kantor Unit Belimbing Cab. Khatib Sulaiman tersebut tersangka gunakan untuk kepentingan sehari-hari tersangka.

5. Tersangka jumlah dana dari hasil penagihan kredit KUR sebanyak 32 Nasabah tersebut yang tidak tersangka setorkan ke teller Bank BRI Kantor Unit Belimbing yaitu sebesar Rp. 44.337.500,- (Empat puluh empat juta tiga ratus tiga puluh tujuh ribu lima ratus rupiah);

Berdasarkan dari keterangan Saksi, Ahli, Surat, Petunjuk dan keterangan tersangka serta dikaitkan dengan barang bukti maka benar diduga telah terjadi tindak pidana perbankan dalam bentuk penggelapan dana nasabah kredit usaha rakyat pada PT. BRI Unit Katib Sulaiman dengan cara sengaja menghilangkan atau tidak memasukkan atau menyebabkan tidak dilakukannya pencatatan dalam pembukuan atau dalam laporan, maupun dokumen atau laporan kegiatan usaha, laporan transaksi atau rekening suatu bank dengan tidak memasukkan atau menyetorkan uang angsuran kredit yang telah diterima oleh tersangka selaku Mantri Unit BRI Belimbing dari nasabah KUR (kredit usaha rakyat) sebanyak 34 orang dengan jumlah Rp. 44.337.500,- (Empat puluh empat juta tiga ratus tiga puluh tujuh ribu lima ratus rupiah) ke dalam laporan transaksi atau rekening kredit nasabah, yang diketahui secara resmi pada tanggal 08 Februari 2019 berdasarkan Laporan Hasil Pemeriksan Pelanggaran Disiplin oleh Tim Pemeriksa pelanggaran Disiplin berdasarkan Surat Keputusan Pimpinan Cabang PT. BRI Cab Khatib Sulaiman Nokep: 02KC.III/HC/01/2019, tanggal 02 Januari 2019.

\section{B. Kendala Dalam Penyidikan Tindak Pidana Perbankan Dalam Bentuk Penggelapan Dana Nasabah Kredit Usaha Rakyat Pada PT. BRI Cabang Katib Sulaiman Berdasarkan Laporan Polisi Nomor LP/198/VII/2019/SPKT Sbr}

Sebelum membahas mengenai kendala dalam penegakan hukum oleh penyidik Ditreskrimsus Polda Sumater Barat, maka penulis akan menyajikan terlebih dahulu faktorfaktor yang mempengaruhi penegakan hukum menurut Soerjono Soekanto sebagai berikut:

1. Faktor Hukum, yakni praktik penyelenggaraan hukum di lapangan ada kalanya terjadi pertentangan antara kepastian hukum dan keadilan, hal ini disebabkan oleh konsepsi keadilan merupakan suatu rumusan yang bersifat abstrak, sedangkan kepastian hukum merupakan suatu prosedur yang telah ditentukan secara normatif. Justru itu, suatu kebijakan atau tindakan yang tidak sepenuhnya berdasar hukum merupakan sesuatu yang dapat dibenarkan sepanjang kebijakan atau tindakan itu tidak bertentangan dengan hukum. Maka pada hakikatnya penyelenggaraan hukum bukan hanya mencakup law enforcement, namun juga peace maintenance, karena penyelenggaraan hukum sesungguhnya merupakan proses penyerasian antara nilai kaedah dan pola perilaku nyata yang bertujuan untuk mencapai kedamaian.

2. Faktor Penegakan Hukum, yakni fungsi hukum, mentalitas atau kepribadian petugas penegak hukum memainkan peranan penting, kalau peraturan sudah baik, tetapi 
kualitas petugas kurang baik, ada masalah. Oleh karena itu, salah satu kunci keberhasilan dalam penegakan hukum adalah mentalitas atau kepribadian penegak hukum.

3. Faktor Sarana atau Fasilitas Pendukung yaitu mencakup perangkat lunak dan perangkat keras, salah satu contoh perangkat lunak adalah pendidikan. Pendidikan yang diterima oleh Polisi dewasa ini cenderung pada hal-hal yang praktis konvensional, sehingga dalam banyak hal polisi mengalami hambatan di dalam tujuannya, diantaranya adalah pengetahuan tentang kejahatan komputer, dalamtindak pidana khusus yang selama ini masih diberikan wewenang kepada jaksa, hal tersebut karena secara teknis yuridis polisi dianggap belum mampu dan belum siap. Walaupun disadari pula bahwa tugas yang harus diemban oleh polisi begitu luas dan banyak.

4. Faktor Masyarakat yaitu penegak hukum berasal dari masyarakat dan bertujuan untuk mencapai kedamaian di dalam masyarakat. Setiap warga masyarakat atau kelompok sedikit banyaknya mempunyai kesadaran hukum, persoalan yang timbul adalah taraf kepatuhan hukum, yaitu kepatuhan hukum yang tinggi, sedang, atau kurang. Adanya derajat kepatuhan hukum masyarakat terhadap hukum, merupakan salah satu indikator berfungsinya hukum yang bersangkutan.

5. Faktor Kebudayaan yaitu berdasarkan konsep kebudayaan sehari-hari, orang begitu sering membicarakan soal kebudayaan. Kebudayaan menurut Soerjono Soekanto, mempunyai fungsi yang sangat besar bagi manusia dan masyarakat, yaitu mengatur agar manusia dapat mengerti bagaimana seharusnya bertindak, berbuat, dan menentukan sikapnya kalau mereka berhubungan dengan orang lain. Dengan demikian, kebudayaan adalah suatu garis pokok tentang perikelakuan yang menetapkan peraturan mengenai apa yang harus dilakukan, dan apa yang dilarang.

Berkaitan dengan faktor-faktor yang mempengaruhi penegakan hukum menurut pendapat Soerjono Soekanto diatas, maka kendala dalam pengegakan hukum oleh Ditreskrimsus Polda Sumatera Barat terhadap tindak pidana perbankan berupa penggelapan dana nasabah kredit usaha rakyat pada PT. BRI Unit Katib Sulaiman pada laporan polisi nomor: LP/198/VII/2019/SPKT Sbr, terdapat kendala-kendala yang telah dikelompokkan dengan kendala internal dan kendala eksternal.

Kendala internal barang bukti uang tidak didapat disita, sebab uang tersebut telah habis oleh tersangka dan pada saat pelacakan rekening diperlukan izin dari BRI pusat, sehingga membutuhkan waktu cukup lama dalam mengumpulkan barang bukti dokumen aliran dana oleh tersangka. Hal ini berkaitan dengan rahasi bank, sebagaimana yang diatur dalam Pasal 1 Ayat (16) Undang-Undang Republik Indonesia Nomor 7 Tahun 1992 tentang Perbankan menyebutkan bahwa rahasia bank adalah segala sesuatu yang berhubungan dengan keuangan dan hal-hal lain dari nasabah bank yang menurut kelaziman dunia perbankan wajib dirahasiakan.

\section{KESIMPULAN}

1. Penyidikan tindak pidana perbankan dalam bentuk penggelapan dana nasabah kredit usaha rakyat pada PT. BRI Cabang Katib Sulaiman berdasarkan laporan polisi nomor LP/198/VII/2019/SPKT Sbr berawal dari laporan pimpinan PT BRI Cabang Katib Sulaiman terdapat penggelapan angsuran dari 32 nasabah oleh mantri yang bertugas 
menagih. Dari hasil penyidikan, uang anggsuran tersebut tidak dimasukkan ke rekening kredit nasabah, namun digunakan untuk kepentingan pribadi. Sehingga berdasarkan keterangan saksi, ahli dan pengakuan tersangka yang didukung barang bukti, maka penyidik menerapkan Pasal 49 Ayat (1) huruf b, Ayat (2) huruf b Undang-undang Perbankan Juncto Pasal 374 KUHP.

2. Kendala dalam penyidikan tindak pidana perbankan dalam bentuk penggelapan dana nasabah kredit usaha rakyat pada PT. BRI Cabang Katib Sulaiman berdasarkan laporan polisi nomor LP/198/VII/2019/SPKT Sbr terdiri dari kendala internal yaitu barang bukti uang tidak didapat disita, sebab uang tersebut telah habis oleh tersangka dan pada saat pelacakan rekening diperlukan izin dari BRI pusat, sehingga membutuhkan waktu cukup lama dalam mengumpulkan barang bukti dokumen aliran dana oleh tersangka. Kendala eksternal yaitu pelapor meminta pemeriksaan dilakukan secara tertutup dengan tidak melakukan olah tkp pada kantor PT. BRI Cabang Katib Sulaiman. Disamping itu lemahnya kewaspadaan masyarakat dengan menitipkan uang angsuran karena enggan datang langsung ke kantor untuk melakukan pembayaran.

\section{DAFTAR PUSTAKA}

Achmad Ali, Menguak Tabir Hukum (Suatu Kajian Filosofis dan Sosiologis), Penerbit Gunung Agung, Jakarta, 2002.

Adhi Wibowo, Hukum Acara Pidana Dalam Teori dan Praktek, Hayfa Pres, Padang, 2012

Feni Dwi Anggraeni, Pengembangan Usaha Mikro, Kecil, Dan Menengah (Umkm) Melalui Fasilitasi Pihak Eksternal Dan Potensi Internal, Jurnal Administrasi Publik (JAP), Vol. 1, No. 6, 2009.

https://www.simulasikredit.com/apa-itu-kredit-usaha-rakyat-kur-kur-mikro-kur-retailkur-tki 